\title{
Tourism Image Asa MediationTourist Satisfaction(A Survey in the Industrial Tourism Object in Cilegon City)
}

\author{
Nurul Afriyani ${ }^{1}$, Endang Ruswanti ${ }^{2}$ \\ Magister Management Esa Unggul University Jakarta Indonesia
}

\begin{abstract}
Tourism is a social phenomenon that attracts the attention of economists, politics, culture, geography, and technology. They offer new concepts by emphasizing specific perspectives, for example tourism is often equated as an industry because this phenomenon is related to the process of developing products and services using a particular technology. Cilegon Tourism Office does not have a clear blueprint for tourism development in Cilegon City. This is evident from the management of places where the attractions are less professional. Attractions in Cilegon is not known of its existence and the utilization of both foreign and local tourists including the opportunities that exist in the attraction.This study consists of five varables covering tourism products, service quality, image to the satisfaction of tourists. The influence of tourism products, quality of service and image to the satisfaction of tourists. Design research used Descriptive design is intended to describe the nature or characteristics of a particular phenomenon statue by not making conclusions that are too far on the existing data because the purpose of this design only collect facts and describe it thoroughly and telita in accordance with the issues to be solved. Design quality, This design is useful to analyze the relationships between one variable with other variables or how a variable affects other variables.
\end{abstract}

Keywords: tourism products, service quality, tourism image and tourist satisfaction

\section{Introduction}

Indonesia as a country located on the equator and has thousands of islands and natural wealth of flora and fauna. The natural beauty of the mountains and the oceans, the beauty of the jungle and its life and the delicacy of its food coupled with the hospitality of its people with various adapat and culture. Indonesia has enormous potential to create a tourism industry (Ohashi\&Kholil, 1995).Much of the research on tourist satisfaction is done. From all the research, generally concluded about the analysis of adnya influence of service quality to consumer satisfaction that is: quality not influenced by service quality. While the dimension of service quality consists of direct evidence, responses, reliability, certainty and empathy. Based on the analysis of regression analysis that the quality of service simultaneously has no positive effect on the quality of tourist destinations. From testing the influence of service quality partially that service quality variable does not affect consumer satisfaction (Musanto, 2012).Cilegon city has the potential to become an advanced tourism destination. The strategic location of Kota Cilegon is located on the northwest tip of Java Island and adjacent to the city of Banten Province. The city of Cilegon is known as an industrial city and a steel city, as it is the largest industrial and steel hub in Southeast Asia. The existing natural and ethnic diversity makes Cilegon City grow in the arts of culture and tourism. Starting from the diverse cultural arts coupled with good tourism religious tours, culinary tours, nature tourism and industrial tourism to make Cilegon not only known as the city of industry and trade. To create tourism potential and expand market target for SME activity, business actor also need to be prepared, especially the perpetrator of SME.Tourism products in the city of Cilegon consists of cultural arts such as Bandrong, Fire Ball, Debus, Lesung and Rudat; Natural attractions such as BatuLawang Mountain, Mount Batur, Pulo Peacock and Small Peacock, Coconut Seven Beach, Pulorida Beach; Religious tourism such as the Tomb of Sheikh Djamaluddin; Artificial tours such as Jogging track, Jungle park, Krakatau Golf Course; Shopping tours such as Krakatau Junction, Cilegon Supermall; Culinary tour like Pondok Palm, Cibeber Night Market; Tourism industry such as Indonesia Power, PT. Krakatau Steel, PT. Krakatau Posko.

\section{Literature Review}

The service industry is now a very large and growing sector of the economy. This growth is in addition to the growth of pre-existing services, also due to the emergence of new types of services, as a result of the demands and technological developments. These developments are ultimately able to provide strong pressure on regulatory overhaul, particularly the relaxation of protection and utilization of new technologies that will directly affect the strengthening of competition in the industry (Lovelock, 2004). This condition directly exposes the business to the increasingly competitive business problems. They are required to be able to identify the form of competition that will be faced, set various standards of performance and recognize well its competitors.Manufacturing companies have now realized the need for a service element in their products as an effort to increase their business's competitive advantage (Hurriyati, 2008). An important implication of this 
phenomenon is the increasingly high level of competition, so that different marketing management services are required compared to traditional marketing (goods).Zeithaml (1996) states that service marketing is about promises, promises made to customers and must be maintained. The strategic framework is known as a service triangle that reinforces the importance of insiders keeping their promise and success in building customer relationships. Triangles describe three interconnected groups that work together to develop, promote and deliver services. These three major players are named on the triangle points: the company (SBU or department or management), customers and providers (providers). Provider may be a company employee, sub contractor, or an outsider who submits the services of the company.Kotler and Keller (2006) suggests the sense of service (service) as follows: Service is any act or performance offered by one party to another party, in principle, intangible and does not cause the transfer of ownership. Production services may be bound or unbound to a physical product.

\section{Tourism Product}

Definition of tourism according to Yoeti (2006) points out that tourism is traveling as the equivalent of the word "travel" so that tourists are "traveler" that is, those who make the trip. Meanwhile, according to Law no. 10 Year 2009 tourism is a wide range of tourism activities and supported by various facilities and services provided by the community, businessmen, government, and local government. Inside tourism many actors are involved. Although their roles vary, but absolutely must be taken into account in tourism planning.

\section{Service Quality}

Parasuraman, et al. (1994) said the quality of service is a comparison between customer perceived service with the quality of service that customers expect. Quality of service centered on efforts in fulfilling the needs and desires of the customer and the accuracy of delivery to compensate expectations from customers (Tjiptono, 2005). Therefore, it can be concluded that the quality of service is the service provided for the fulfillment of expectations or expectations from customers. Services can also be interpreted as services that berupakecepatan, amenity, hospitality and ability shown through attitude in providing services for customer satisfaction. According to Parasuraman, et al. (1994) argues that: quality of service (service quality) is how far the difference between reality and expectations of customers for the services they receive / acquire.

\section{Tourism Image}

Corporate image according to Adona (2006) is the impression or mental impression or a picture of a company in the eyes of its audiences formed based on their own knowledge and experience. Citra intentionally need to be created so that is positive (Soemirat, et al., 2007). Positive things that can enhance the company's image through company success and history or company history. Thus, the image of a company is a representation of an institution in the hope of being able to encourage a positive corporate image. According to Kotler (2004) corporate image formed from associations between companies with a set of positive and negative attributes. Melewar (2008) revealed that the image can be formed from personality, strategy and corporate identity. Can be concluded that the image of the company is a picture or impression felt by customers as a result of services provided.To improve tourism and tourism marketing, image is a factor affecting demand. From this point of view the image consists of an objective level of enlightenment, impressions, prejudices, dreams, hopes, emotions and thoughts that determine tourists to choose their holiday destinations. Given the definition of image is a perceptive phenomenon that shapes the mind of the consumer logically-emotional image should have cognitive and emotional components (Baloglu, 2002). The image of the destination is the individual's perception of the characteristics of the destination that can be influenced by promotional information, mass media and many other factors (Kozak andRimmington, 2000).Imagery is an interpretation of the results of consumer evaluation and emotion as a result of two important components of cognitive and affective imagery (Hosany and Ekinci, 2007). Cognitive imagery more referring to consumer knowledge and trust, while the affective image is more on the feelings of a particular object. This research adopts several items that cover both cognitive and affective imagery.

\section{Tourism Satisfaction}

According to Tjiptono (2005) argued about the definition of customer satisfaction is: the word satisfaction derived from the Latin "Satis", which is quite good and adequate, while "Facio" means do or make. So satisfaction can be interpreted as "effort fulfillment something". Meanwhile, according to Kotler \& Armstrong (2013) that customer satisfaction is a feeling of pleasure or disappointed a person after comparing the performance of the product thought to the expected performance of the product. Meanwhile, according to Irawan (2004) that customer satisfaction can be regarded as a qualitative measurement of the output consumed or used by consumers.Customer satisfaction by Tjiptono (2005) is the level of one's feelings after comparing the performance (or outcome) that he perceives compared to his expectations. According to Park (2003) customer 
satisfaction is a consumer feeling as a response to the product goods or services that have been consumed. In general, satisfaction can be interpreted as a comparison between services or results received by consumers with consumer expectations, services or results received it must be at least equal to the expectations of consumers, or even exceed it.

Ruswanti (2012) in her research concluded that costumer satisfaction is a feelinh resulting from an evaluation process about what is received on what to expect including the purchase decision of the goods itself, as well as the needs and desires associated with the purchase.

\section{Conceptual Framework and Hypotheses}

From some research above, there are differences with research that will be done by the researcher, that is tourism product, service quality as independent variable, image as intervening variable while the satisfaction of tourists is as dependent variable, as in the picture below:

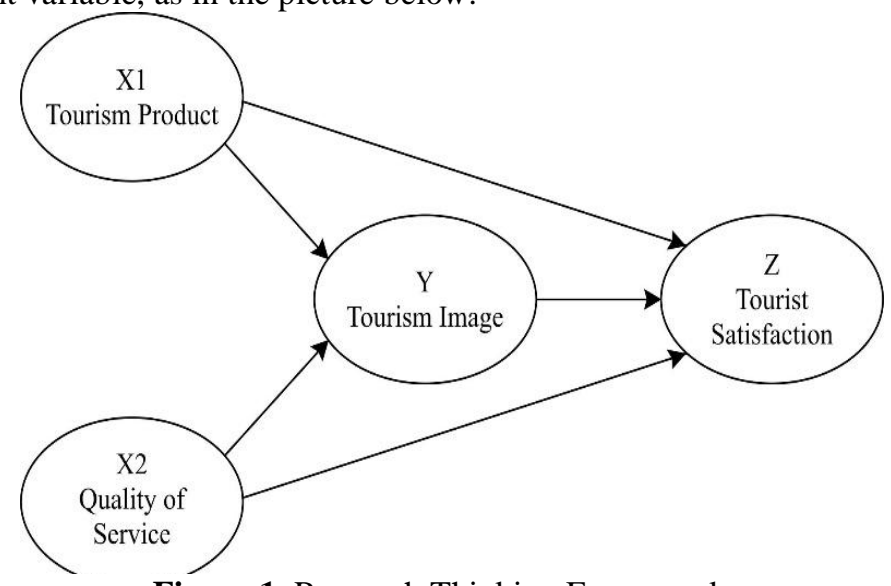

Figure 1. Research Thinking Framework

Description: X1 = Tourism Product, $\mathrm{X} 2=$ Quality of Service, $\mathrm{Y}=$ Tourism Image, $\mathrm{Z}=$ Tourist Satisfaction In this research as the research hypothesis is

1. Tourism products affect the satisfaction of tourists

2. Tourism products affect the image

3. Quality of service affect the satisfaction of tourists

4. Quality of service affect the image

5. Image affect the satisfaction of tourists

6. Tourism products, service quality and image affect the satisfaction of tourists

\section{Research Model}

This study consists of five varables covering tourism products, service quality, image to the satisfaction of tourists. The influence of tourism products, quality of service and image to the satisfaction of tourists.

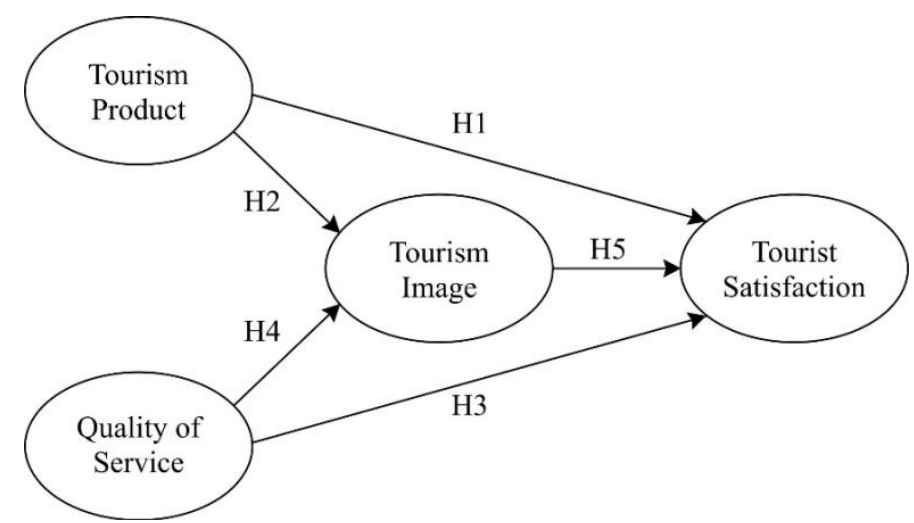

Figure 2. Research Model

Information:

Travel Product $=$ independent variable 1

Quality Service $=$ independent variable 2 
Travel Destinations $=$ Variable intervening

Traveler satisfaction $=$ dependent variable

\section{Research Development}

In this research as the research hypothesis is

\section{H1: travel products affect the satisfaction of tourists}

According to Denis (1994) states that the quality of service affects customer satisfaction, trust, and resilience of customers and ultimately bring profit.

Perception of the quality of tourist destinations perceived by tourists during and after visiting tourist destinations is the quality of tourism and affect the satisfaction of tourists.

\section{H2: travel products influenced the image}

Tourism products have a significant correlation to the image that is defined as a positive marketing activity in order to influence the consumer's decision to visit it (Blain, et al., 2005). Dimensions or indicators of destination image variables, developed based on corporate image dimensions (Keller, 2003).

\section{H3: The quality of service affect the satisfaction of tourists}

Normasari, et al. (2013) conducted research on the influence of quality of service to customer satisfaction, corporate image and customer loyalty (Survey on customers who stay at Pelangi Hotel Malang). The results showed path analysis (path analysis).

\section{H4: the quality of service affect the image}

Image if linked to customer satisfaction is a supporter of the management function which always creates identity and loyalty. Creating a positive image is an achievement. In customer relations the most important thing is the acquisition of understanding of customer satisfaction and gain public support for the company has a good image. In the relationship variable quality of service as an independent variable that affect the image and customer satisfaction.

\section{H5: image affect the satisfaction of tourists}

Sach (2010) concluded that the image can be a kind of communication that gives explanations and convinces the prospective traveler about goods and services with the aim to gain attention, educate, remind and convince potential tourists. A well-designed tourist attraction will provide additional local revenue, and encourage the multiplier process of local economic development around the tourist destination.

\section{Methodology}

Research observed tourism product and service quality as independent variable, tourist satisfaction as dependent variable, and image as intervening variable. Furthermore, the four research variables are operationalized in the following table:

Table 1: Operational Variables

\begin{tabular}{|c|c|c|c|}
\hline $\begin{array}{l}\text { Research } \\
\text { variable }\end{array}$ & Dimensions & & Operationalization \\
\hline \multirow{5}{*}{$\begin{array}{l}\text { Tourism } \\
\text { Products }\end{array}$} & \multirow[t]{2}{*}{ Attractions } & 1. & Nature tourism in the city of Cilegon well preserved. \\
\hline & & 2. & Cultural tourism is still preserved. \\
\hline & \multirow[t]{2}{*}{ Accessibility } & 3. & Easily accessible tourist sights \\
\hline & & 4. & To reach the tourist attraction the availability of easy transportation tool. \\
\hline & Networking & 5. & Tourism actors organize tourism products in cooperation with other agencies. \\
\hline \multirow{6}{*}{$\begin{array}{l}\text { Service } \\
\text { quality }\end{array}$} & Tangibility & 6. & Tourists get the convenience of service and information \\
\hline & Reliability & 7. & Officers reward tourists \\
\hline & Responsiveness & 8. & The services provided are fast and efficient. \\
\hline & \multirow[t]{2}{*}{ Assurance } & 9. & Officers help tourists deftly \\
\hline & & 10. & The clerk behaves politely and well mannered in serving tourists \\
\hline & Emphaty & 11. & At tourist attractions available information center \\
\hline \multirow{3}{*}{$\begin{array}{l}\text { Tourism } \\
\text { Imagery }\end{array}$} & Professionalism & 12. & Tourists feel happy to visit the attractions \\
\hline & Modern & 13. & Tourists enjoy the facilities provided and modern technology. \\
\hline & $\begin{array}{l}\text { Serving All Tourist } \\
\text { Segments }\end{array}$ & 14. & $\begin{array}{l}\text { Tourism actors are willing to receive input both suggestions and criticism from } \\
\text { visitors }\end{array}$ \\
\hline \multirow{5}{*}{$\begin{array}{c}\text { Traveler's } \\
\text { Satisfaction }\end{array}$} & Product quality & 15. & Existing tourist products guarantee and quality \\
\hline & Service quality & 16. & Tourists prioritize excellent service to visitors. \\
\hline & Emotional & 17. & Travelers feel to have and want to visit again. \\
\hline & \multirow[t]{2}{*}{ Price / Cost } & 18. & The price offered, tourists never feel the disappointment \\
\hline & & 19. & Tourists feel the price charged by the tourism actors is affordable. \\
\hline
\end{tabular}




\section{Result}

The population in this study are the tourists (foreign and domestic) who do industrial tourism in the city of Cilegon the number 91,924 people based on the data of tourist visits in 2015 (Disbudpar Kota Cilegon, 2015). While the sample of research is determined as much as 190 taken from tourists who visit in eksidental technique. The method of data analysis in this study by using Structural Equation Model (SEM). According to Hair et al. (2008) underlines the appropriate sample size for SEM is 100 to 200. In addition the minimum sample determination for SEM by Hair (2008) is dependent on the number of indicators multiplied by 510. Referring to the calculation of minimum and maximum number of samples available, the number of samples selected for this study is based on multivariate 4 variables and 15 indicator means that there are 19 parameters.This study tested the hypothesis with multiple regression analysis (multiple regression) expanded by the method of path analysis (path analysis) for testing the effect of intervening variables. The path analysis function used is to determine the influence strength of each variable to see the indirect influence of each of the variables contained in the research model (Ghozali, 2006). Path analysis gives explicit causal relationships between variables based on the theory. The arrows show the relationship between variables. Each $\mathrm{p}$ value represents the path and path coefficients. Based on the path model drawing proposed relationship based on the concept that tourism products have a direct relationship of tourist satisfaction (p1). However, tourism products also have an indirect relationship to the satisfaction of tourists from tourism products to the image (p2) and then to the satisfaction of tourists (p3). Then the path model is also proposed relationship based on the concept that the quality of service has a direct relationship of tourist satisfaction (p4). However, the quality of service also has an indirect relationship to the satisfaction of tourists from the quality of the waiter to the image (p5) and then to the satisfaction of tourists (p6).Furthermore, if the results of the data in this study resulted in $a$ path diagram as shown below:

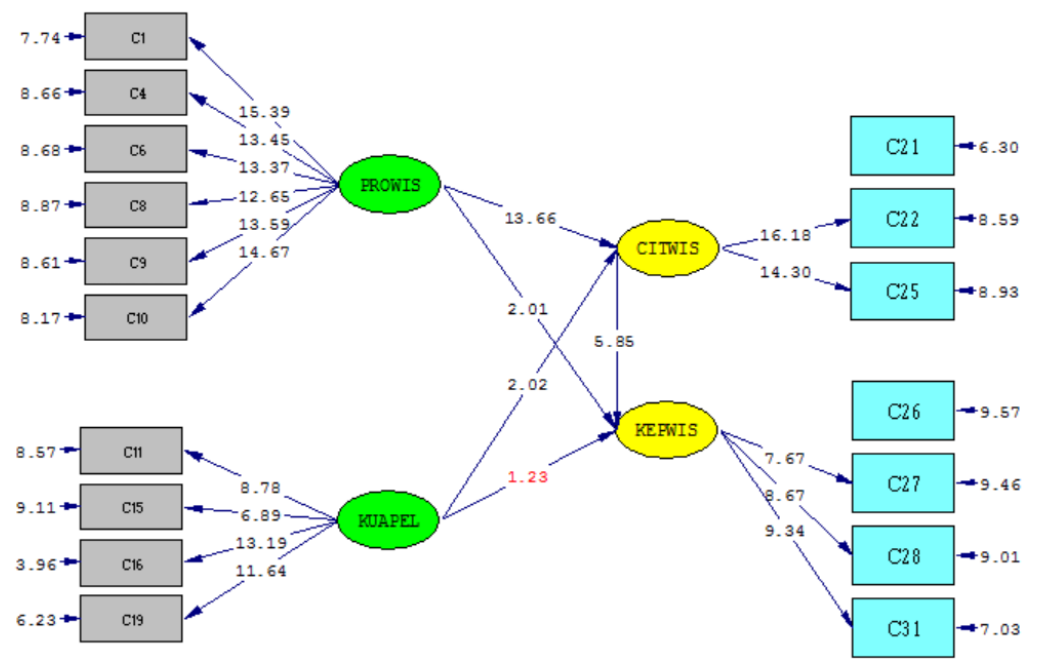

Chi-Square $=298.54, \mathrm{df}=113, \mathrm{P}$-value $=0.00000, \mathrm{RMSEA}=0.093$

Image: Path Diagram T-Value

The research results obtained are as follows:

Table: Hypothesis Testing Research Model

\begin{tabular}{|c|l|c|c|}
\hline Hypothesis & \multicolumn{1}{|c|}{ Hypothesis Statement } & Value $\boldsymbol{T}$-Value & \multicolumn{1}{c|}{ Information } \\
\hline $\mathrm{H}_{1}$ & $\begin{array}{l}\text { There is the influence of travel products to } \\
\text { travel satisfaction }\end{array}$ & $\begin{array}{l}\text { Data support the hypothesis } \\
\text { There is the influence of tourism products on } \\
\text { the tourist image }\end{array}$ & $\begin{array}{l}\text { The data support the } \\
\text { hypothesis }\end{array}$ \\
\hline $\mathrm{H}_{2}$ & $\begin{array}{l}\text { There is no effect of service quality on } \\
\text { tourism satisfaction }\end{array}$ & $\begin{array}{l}\text { The data do not support the } \\
\text { hypothesis }\end{array}$ \\
\hline $\mathrm{H}_{3}$ & $\begin{array}{l}\text { There is influence of service quality to } \\
\text { tourism image }\end{array}$ & $\begin{array}{l}\text { The data support the } \\
\text { hypothesis }\end{array}$ \\
\hline $\mathrm{H}_{4}$ & $\begin{array}{l}\text { There is influence of tourism image to the } \\
\text { satisfaction of tourism }\end{array}$ & $\begin{array}{l}\text { The data support the } \\
\text { hypothesis }\end{array}$ \\
\hline $\mathrm{H}_{5}$ & & 5.85 & 23.02 \\
\hline
\end{tabular}




\section{Discussion}

In the results of the first hypothesis testing (H1), it was found that the analysis results support H1 hypothesis that there is the effect of tourism products on tourism satisfaction of $2.01(>1,96)$. This shows that the satisfaction of tourists influenced by tourism products. The current state of the tourist product is superior to provide travel satisfaction.In the second hypothesis test results ( $\mathrm{H} 2)$, it was found that the results of the analysis support $\mathrm{H} 2$ hypothesis that there is influence between tourism products on tourism image of 13.66. This shows that the image of the tourist is influenced by the tourism product owned by the company. The better the tourism product will improve the image of tourism.In the results of the first hypothesis testing $(\mathrm{H} 3)$, found that the analysis results do not support $\mathrm{H} 3$ hypothesis that there is no effect of service quality on tourism satisfaction of 1.23 (below 1,96). This shows that the quality of service is not influenced by the satisfaction of tourists. The current state of service quality is unseeded has not been able to provide the satisfaction of tourists. In the results of the fourth hypothesis testing (H4), it was found that the results of the analysis support $\mathrm{H} 4$ hypothesis that there is influence between the qualities of service to the tourist image of 2.02. This shows that the image of tourism is influenced by the quality of serviceIn the results of the fifth hypothesis testing (H5), found that the results support the hypothesis H5 ie there is influence between the image of tourism on tourism satisfaction of 5.85. This shows that the satisfaction of tourism is influenced by the image of tourism

\section{Managerial Implication}

Related to tourism product as an important factor affecting the satisfaction of tourists, the dimension of tourism product turns out to have the strongest influence for market orientation. This is seen from the high factor loading value of 2.01 (seen in Figure 5.10). Based on these findings the policy steps that can be submitted are for the company to continue to have an insight into the development process or to seek tourist information to increase the satisfaction of tourists, handle customer complaints well and company regularly measure customer satisfaction and find ways to offer more value to tourists. Increasing the competitiveness of tourism products, entrepreneurs can make changes and modifications to the product in a direction that is more in line with the demands and needs of consumers are always changing, so that consumers remain interested in choosing products offered. A feature of a tourism product that has a competitive advantage is characterized by the ability to understand changes in market structure and able to choose an effective business or marketing strategy.

\section{Conclusion}

This study examines the effect of market orientation and product innovation on competitive advantage to improve marketing performance. The results of the study can be summarized as follows: The first hypothesis (H1), found that the satisfaction of tourists influenced by tourism products. The current state of the tourist product is superior to provide travel satisfaction. The second hypothesis (H2), found that the image of tourism is influenced by tourism products owned by the company. The better the tourism product will improve the image of tourism. The first hypothesis (H3), found that the quality of service is not influenced by the satisfaction of tourists. The current state of service quality is unseeded has not been able to provide tourism satisfaction. Fourth hypothesis (H4), found that the image of tourism is influenced by the quality of service. The fifth hypothesis (H5), found that the satisfaction of tourism is influenced by the image of tourism.

\section{Limitations of Research}

Although this research contributes to the results achieved in previous studies, there are still some limitations to be addressed by future researchers, namely: (1) There is a possibility that respondents do not actually fill in, causing the measurement to be used is not Describes the variables significantly; (2) The object of this study is certainly not possible to be made conclusions generally accepted if applied to other objects outside the object of this study. (3) In response to the image of tourism, it is not possible that in fact there are still other factors that may affect the satisfaction of tourists.

\section{Suggestion}

In order to improve marketing that will have a positive impact on competitive advantage, it is necessary Product innovation in order to give space to improve the competitiveness of companies against competitors. Such suggestions may be contained in managerial implications. As for future research, should conduct research on other objects. Future research can also replicate research by taking objects on other aspects that can boost the image of tourism. This is intended to determine whether there will be differences in research results between image and satisfaction of tourists. This research recommends to investigate this problem by adding influence of other factors influencing competitive advantage. One of the factors that can be added is the marketing used. As a business that offers services then the role of media marketing is crucial for the success of tourism in raising the image and satisfaction of tourists. The existence of such research is expected to be known whether the marketing can indeed be used as one source to achieve the image and led to the satisfaction of tourists. 


\section{References}

[1] Adona, Fitri. 2006. Citra danKekerasandalamIklan Perusahaan di Televisi. Padang: Andalas University Press.

[2] Baloglu, Seyhmus (2002).॥ Dimensions of Customer Loyalty-Separating Friends from Well Wishers I Cornell Hotel and Restaurant Administration Quarterly, Cornell University.

[3] Hair, Joseph F, Jr., Bush, Robert, P., and Ortinau, David, J. 2008, Marketing Research Within a Changing Information Environment, 3rd Edition, McGraw-Hill, New York.

[4] Hosany, S., Y. Ekinci., and M. Uysal. 2007. Destination Image and Destination Personality. International Journal of Culture, Tourism and Hospitality Research, 1 (1). pp 62-81

[5] Hsu. Chaty H.C. and Powers, Tom. 2002. Marketing Hospitality,. New York, USA: John Wileys\& Sons, Inc.

[6] HurriyatiRatih. 2008. BauranPemasarandanLoyalitasKonsumen. Bandung, Alfabeta

[7] Kotler, Philip, dan Keller, Kevin Lane. 2013. Marketing Management : Fourteenth Edition, New Jersey: Prentice-Hall Inc.

[8] Kozak, M., \& M. Rimmington. (2000). Tourist Satisfaction with Mallorca, Spain as an Off-Season Holiday Destination. Journal of Travel Research. Volume 38. No. 3.

[9] MusantoTrisno (2004) Faktor-FaktorKepuasandanLoyalitasPelanggan :StudiKasuspada CV Media Sarana Advertising Surabaya.JurnalManajemen\&Kewirausahaan Vol. 6, No. 2, September

[10] Ohashi\&Kholil (1995). A Comparison of Response Styles in Singapore and Taiwan, New York: The Haworth Press.

[11] Parasuraman, A., Zeithaml, V.A dan Berry, L.L., 1994, "Reassessment of Expectations as a Comparison Standart in Measuring Service Quality : Implication for Further Research", Journal of Marketing, January ,111:124.

[12] Ruswanti, E. (2012). Pengaruh Service Quality dan Customer Satisfaction Terhadap Customer Loyalty. Widya Tahun 29 nomor 318 Maret 2012. pp 49-54.

[13] SapoetroTonno, (2014) TonnoSapoetroDirekturUtama PT Krakatau Bandar Samudera, Tata Kelola Bandar Berkelas, Majalah Peluang.com, 13 November 2015, http://majalahpeluang.com/tonno-sapoetro-direktur-utama-pt-krakatau-bandar-samudera-tatakelola-bandar-berkelas/

[14] Soemirat, Soleh\&Ardianto, Elvinaro, 2007, Dasar-dasar Public Relations, Bandung, Rosdakarya. Dasar-dasar Public Relations, Bandung, Rosdakarya.

[15] TjiptonoFandy (2005) Service Quality and Satisfaction, PenerbitAndi Yogyakarta.

[16] Yoeti A Oka, (2006) PariwisataBudaya :MasalahdanSolusinya, PradnyaParamita

[17] Zeithaml, V.A,. Berry, L.L., and Parasuraman, A, 1996, The behavioral consequence of service quality. Journal of Marketing. Chicago: Vol. 60, No.2. 